第 1 日 第 2 会場（9.00 12.00）一般潰題19～36（病理，a-fetoprotein，免疫）

司会 大阪大学病理 宮 地徹
東京大学病理 志 方 棇 夫

\section{9. 肝のインドシアニングリーン移送に関する奄子顕 铰鏡的钼察}

順天堂大学内科 (消化器)

黒田 博之, 今 哲二, 馬原 敬二

林 敬民, 山口 鹳一，浪久 利彦

目的：インドシフニンダリーン（ICG）を血中に 投与すると，そのはとんどすべてが肝細胞に取り込ま れ，その後胆汁中に撕墈されるが，本色素は水溶性であ るため,これを形態学的に観察することは困難であつ た. われわれは本色素を組織内に沈没固定し電顕的に観 察し, 肝細胞における色素移送の実態を形態学的に観察 しょらとした.

方法：ラッテ尾静脈および門脈より I C G 10mg/kgを 注入した後，肝摘出を行ない実検に供した，前固定と しては，タルタールフルデヒド，カコジール緩衡液拈よ び塩化第 2 鉄によりおこない，硫化フンモンにて硫化 後, オスミウム酸で後固定した。脱水後エポン $812 に て ~$ 浸透硬化を行なつた．票本を薄切，無染色，ウラニール 単染色, ウラニール鉛二重染色して奄子䫒碳鏡的に観察 した.

成績：1. I C G 顆粒の確認：I C G 湔記の前固定 液により沈澀し、これを瞙はリォッシュにより観察す ると直径 $10 \AA$ から $30 \AA$ の dense な顆粒として見られ，ま た I C G 注入肝と対照肝とを比較すると，注入肝机おい ては，上記と同様な顆粒が肝組織内にみられたが，対照 䀒においては、これらの顆粒はみとめられなかつた。 2. 肝組瀻内分布：I C G 顆粒は類洞, Disse 腔, 毛細胆 管, 肝細胞小胞体就びリソソームにみとめられ，基 質, ミトコンドリフ, 脂肪滴, ミクロボディー, 核には 認められなかつた. ただし，ミクロソーム内には，対照 においても類似の顆粒が認められたので，I C G 顆粒の みか否かの断定は不可能であつた. 3. 注入後の時間に よる変化：I C G 顆粒は， I C G 注入後30秒の標本にお いてはすでに類洞および Disse 腔内にみとめられ，60秒 の標本に捻いてはすでに胆管内化認められた，4. 注入 部位による変化：門脈あるいは尾静脈より I C G を注入 した場合，肝組織内に和ける I C G 顆粒の分布に差はみ られなかつた。

結論：I C Gは塩化第 2 鉄により沈澱しこれを硫化 することにより奄顕的に顆粒として認めることが可能 であつた。この方法により肝組織内 I C G の存在を確認 した. 2. I C G 投与後, 顆粒は類洞, Disse 腔, 小胞 体およびリソソームに認められたことから，I C G の肝 内に拉ける移送は，上記のオルガネラの順におこなわれ るむのと考えられ，その詳細について検討した。
20. 奏駼的 Intrahepatic cholestasis における湦面 小胞体の意䓯について 広島大学医学部第一病理学教室 円山 英昭 広大原医研 飯島 宗一

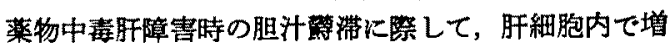
生する滑面小胞体(s-ER)の意義についててはいまだ不明瞭 な点が少なくない，私達は実験的に intrahepatic cholestasis を生ぜしめ, 萀起された s-ER の増生像と黄疸発生 機序との関連について検討を試みた。

方法：wistar 系ラット雄（200〜 400gr） K, ANIT ( $\alpha$-naphthyl-isothiocyanate) をコーン油に溶解後, 胃管 を利用して経ロ一回投与し，無麻醉下䫓動脈切断により 屠殺した。

第一群：時間的観察 (A N I T 投与量一定, 投与後屠 殺までの時間を变えた群一 6 時間〜 9日後).

第二群：投与量による差異（一律に投与48時間後に屠 殺, 体重视当りの投与量を加減した群一25〜 500mg/体重 $\mathrm{kg})$. 両群において生ずる i.c. を電顕的, 血液化学的およ び酵素組緛学的に観察すると同時に，同系のラットに総 胆管結禁切断を行ない, 一, 二群との比較対照に供した。

結果: 第一群の観察では, 投与 48時間後飞 血液化学 検査上, 最も強い肝障害 (G P T 709単位) と黄㾝の出 現（総ビリルビン值 $7.0 \mathrm{mg} / \mathrm{dl}$, 直ビ $5.7 \mathrm{mg} / \mathrm{dl}$ ) が観察さ れるが，4 日目にははとんど正常值 (GP T 64, 総ビ 0.9）を示した，投与量を变えた場合には， $\mathrm{LD}_{50}$ （ 300 $\mathrm{mg} /$ 体重 $\mathrm{kg}$ ）を越えると，上昇したG P T 值は次第に下

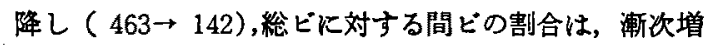
加する $(17 \rightarrow 50 \%)$.一方, 超微構造上では, 黄㾝発生群 はいずれる程度の差こそあれ，毛細胆管の著しい変化と 同時に，肝細胞内に梅䧴な網状構造を示して集積した s-ER の強い增生像が認められ，その増生の様子と黄疸 の程度拉よび経過とは比較的相関した。 しかし一方で， 同程度の黄㡺を示した総胆管切断群では, s-ERの増生は 差程強くはない，肝組織ては，その他細胆管の增生と， 場所によつて肝細胞の壊死像が散見され，醉素組織学的 には，毛緗胆管部の ATPase 活性の低下が観察された。

結論：A N I Tによるi.c.は主として肝細胞障害性で あり，その主要な発黄機序の一つとして，毛細胆管部 に打ける超微構造上の変化と, ATPase 活性低下とに反 映される胆汁排泄機能障害があげられる.一方で, s-ER 增生は，血液化学的に同程度の黄誼を示した総胆管切断 群において，差程強くなく，また無黄庭性に経過する 脂溶性薬物投与時に, 薬物代謝醭素誘導を伴 5 , 異常な s-ER の増生が知られており，A N I T 投与時の s-ER の 增生は, 䀝溶性A N I T の除去分解のため巨肝細胞の積 極的機能相の表現とも考光られる。 
21、汗における線維吸収過程 (dysclasia) の乨顯的 観察

$$
\begin{aligned}
& \text { 慶大三刃内科 } \\
& \text { 織田 正也，岡崎 勲，加茂絃一郎 } \\
& \text { 亀谷麇与隆, 土屋 雅春, 三功 謙 }
\end{aligned}
$$

目的：演者らは， $\mathrm{CCl}_{4}$ 傷害 $ッ$ ッ肝の線䧽化ならび に線維吸収過程において，膠原線維の消長と lysosome 醭素活性の変動とが密接な関係をるつことを報告してき たが，今回は一旦形成された周原線維の吸收・消失過程 における肝の超微形態を線維化進行時のそれ之比較し, 同時に酸性粘液多䊰（AMPS）の消長につき険討を加 穴，線維吸収機転に衫汁る肝細胞㧍よび間葉系細胞の役 割の一面を明らかにする。

万法：体重 $200 \mathrm{~g} の$ Wistar 采崔性 ラットを用い, $\mathrm{CCl}$ 、を体重 $100 \mathrm{~g}$ 当 $00.15 \mathrm{ml}$ 遇 2 回皮下注射し， 4 週 ( I 群)，5週（II 群），8週 (III群) 㧊よび12週 (IV群) 後にそれぞれ 5 匹をエーテル麻酔下で開腹，訮の一部を 切除し, 光顐的, 組織化学的ならびに電顕的観察を行な

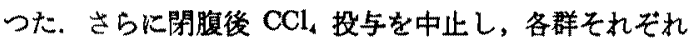
$2 ， 1 ， 3 ， 3$ 週間放置後断頭屠殺 L, 肝を同様に観察 した. A M P S の存在は toluidin bleu, Ruthenium Redお よびジアスターゼ消化後P A S 反応で確かめ, lysosome 醭素活性はazo 色素法により組織化学的に検討した。

成績：各群の $\mathrm{CCl}_{4}$ 中止時肝組絨所見は線維化が著明 で，III，IV群では活ば全例が硬変肝の像を示した．主と してI，田群において，啳殺時光顕レベルで線維がほぼ 消失している例では $\mathrm{CCl}_{4}$ 中止時にみられた lysosome 酵素活性の低下は回復し，AMP S の貯蓄るみられず， 䉓顕的には線維形成時に認めた肝細胞内 r-ER の著明な 空胞化, s-ERの局所的增生, 脂蛋白様物質の瞎溜等の変 化はほとんどみられず，消失傾向にあつた primary 1ys。 osome すほぼ正常に復し, cytolysome は消失している. $\mathrm{CCl}_{4}$ 投与 8 週以後に目立つた Disse 腔側肝細胞 microvilli の平担化，搪大したDisse 腔内における無定形物質 の沈着および細線維の増生は認めず，microvilli はほほ 正常像を呈し, Kupffer 細胞あるいは macrophage 内の lysosome および phagosome は正常時に較べ目立つ。一 方，屠殺時に線維が残存した例（主としてI，IV群）で は，電䫒的には肝細胞間またはD Disse 臆内に显原線維が 散見されるが，その近傍にAMP S と思われる無定形物 質が沈着し，肝細胞内では小器管の变化ととるに に lysosome は減少し, 細胞 microvilli の減少 - 消失傾 向が残存する.

結諭：肝線維化過程でみられた肝細胞の势的变化， 特に primary lysosome, ER および肝細胞膜の正常化, 間葉采細胞ならびに肝細胞内 lysosome 醳素活性の回復 およびA M P S の消失は，一旦形成された原線維の吸 収に有利な場を提供する。
22. 日本住血吸虫症に於ける肝硬变症の実験的解析 信州大学医学部第一病理学教室

加茂 悦雨，浅野 正英，河合 博正

目的：日本住血吸虫（以後日虫と略す）拝の肝病変は その寄生した虫卵内物質の宿主に対する抗体産生により 惹起される事は免疫血清学的方法等により確認され初め ている.今回の実験目的は日虫症の䀒硬変症の成因を家 鬼を用い実験的に解析し，乙の線䧽化，偽胆管形成等の 変化は虫卵による門脈血流障害による以外に，自己免疫 学的反応として生ずる事を明らか比することにある。

方法：成热家鬼67羽を用い，第1群として日虫七ル

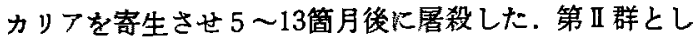
て日虫奇生家鬼の肝を Freund complete adjuvant (以後 F CA）をとすにホもジェネートにし， $0.1 \mathrm{ml}$ を10简 所皮内， $1 \mathrm{ml}$ を 2 箅所筋注（各 1 回）し，3 筒月（一 部は 2 箇月）後に屠殺した，第茿群として正常家鬼肝を F CAととbにホモジネートにし同様注射後 3 筒月（一 部は 2 简月）で屠殺した。第IV群としてFCAのみを同 樣に注射し 3 䇫月（一部は 2 筬月）後屠殺した。

成績 : 肝の変化 : 第 I 群では所謂 Pipe stem cirrhosis の像を呈し虫卵を有する肉芽腫と著明な線維化が認か られ，浸潤細胞は他群に比し偽好酸球・形質細胞が多 く、リンハ球す見られる. 線維化部には偽胆管も認めら

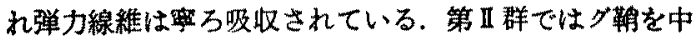
心に著明な線稚化ととすに偽胆管の形成が著しく，細胞 浸潤は主にリンパ球で為好酸球多認められる。肝実質に む肝細胞壤死を伴らリンハ球，偽好酸球浸潤のある小さ

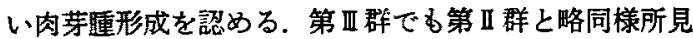
を呈するが，グ氏䩗の線維化部の線維化は稍々軽度であ るとともに，偽胆管形成はかなり軽度である．肝寒質の 変化は第I群に比べはとんど存在しない，第IV群ではク 氏䩪に他群に比しきわめて軽度のリンパ球，偽好酸球の 浸潤を認めるのみである．その他の践器の変化：第 I 群 では肉芽腫は肺，リンバ節にも認められ，脾は軽度の Fibroadenie の像である．第I，群共，脾は著明なう つ血で時に Fibroadenie の像を認めた。

結諭 : 家鬼を用い日虫セルカリアを寄生させ肝硬変 症を生じさせた。ささら日虫寄生肝と F C A および正常 肝とFCAのホそジネートの皮内，等注に上り肝硬变症 を生じさせ，特に前者では線維化，肝再生像がより強度 に若起でた。その結果血清 $\gamma$-グロブリンの上㫒所見 とともに，日虫症の肝硬変症は虫卵による門脈血流障害 の成因の他に自己免疫学的反応としての肝再生を伴う線 維化が成因になっている事を明らかルした。 
23. 訮癌確定診断および悪性度分類における Aspiration Biopsy $の$ 価值

長崎大学医学部第 2 外科

赤司 光弘，樋口 楼，林 輝義 古川 正人, 内村 正幸, 土屋 凉一

目的：私達は出血による危険性むなく, 安全にかつ容 易にできる経皮的 Aspiration Biospy を施行することに 上り，盰癌の確定祅断を Aspiration Biopsy 細胞竞から 得ているので，その方法および成綨を報告し，から䠛床 的診断価値を検討した。

方法 : 細胞固定液 (エーテルアルコール混合液 $2 \mathrm{cc}$ ) を23ゲージの注射針をつけた10cc注射器に入れる.これ を用いて，表在性に触知する場合は，睡大した肝や腫瘤 に経皮的に刺入し，強く吸引することにより腄婸内容物 や細胞群を吸引採取する．たと之肝や腫瘤が実質性に固 くてあ診断に充分な細胞群は吸引されてくる. 表在性に 触知しない症例でも，矸シンチ，血管撮影などを参考に して腫渲占居部位を推定し，吸引部位を决定する。この

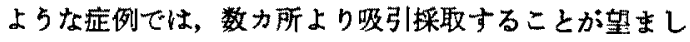
い。くて，細胞固定液中に採取された吸引採取液の沈 渣より Papanicolaou 染色染抹標本と, H.E 染色 Cellblock 漂本を作製する.

成辕：昭和 46 年 3 月まで, 肝腫湯を疑つた 34 例に Aspiration Biopsy を施行した。その内訳は原発性肝癌12 例, 転移性肝癌10例, 肝重腫 2 例, 血管尰 1 例, 肝硬変 6 例, 肝膿瘍 3 例である. 原発性肝癌 12 例の5ち10例 (83\%),転移性肝癌10例の5ち 8 例 (80\%) 飞 Aspiration Biopsy 細胞診で Positive の猃断をらけ, 衍前確定診断

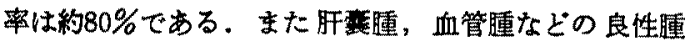
湯，および肝膿瘍は Aspiration Biopsy 細胞診で示唆す ることができた。一方，肝硬変の場合 Aspiration Biopsy 細胞診では Negative の診断を得るのみで肝硬変の確定 診断はできなかつた。なお，術時又は剖検時の所見で穿 刺部位の出血, 胆汗洩出は諗められていない、さらに, Aspiration Biopsy 細胞診による胿癌細胞の確認以外に 肝癌の悪性度分類の可能性を検討するために見在まで， 剖検肝癌 20例を使用して Aspiration Biopsy 細胞診所見 と切片標本による組鐡所見との比較検討をおこなつた。 その結果 Aspiration Biopsy 細胞跈の 悪性度分類と組織 標本によるそれとは注隹致し，Aspiration Biopsy 綀 胞診のみで䀒癌の悪性度分類も充分可能であることを確 認した.

結論：1）Aspiration Biopsy は肝尰瘍症例に対し, 経 皮的に出血，胆汁洩出の危険性なく，容易に施行でき る、2）Aspiration Biopsy 細胞診による肝癌の術前確定 診断率は，現在まで約 $80 \%$ であり，さらにその悪性度 分類も可能である。3）良性肝腫痬，肝朖瘍も示唆でき る.
24. キノフォルムによる肝内閉塞性黄㾝の病理 東京大学病理学教室

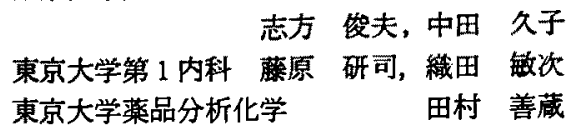

目的：最近SMONがキノフォルム中毒であるといら 考え方が強くなるにつけ，肝におけるキノフォルムの代 謝，排泄等が問題になっているが，これとは別に人体例 で肝内閉塞性黄疸がキノフォルムにより括こる事をわれ われは見出した。本研究はキノフォルムによる肝内閉塞 性黄疸の実態を明らかにし，また動物実験でその発生機 転を解明せんとするすのである。

材料就よび方法：臨床的に肝内閉塞性黄疸之診断さ れ，剖検された 4 例の应例がその対象である。，他の原 因による閉塞性黄疸括よびS MON の症例比較検討し た。これらの肝組織からガストロマトクラフィーでキ। フォルムの検出が行なわれた．動物実験はラットおよび 鬼を用い，キノフォルム投与後主として電顕的検索を行 なった.

成績：旰内閉塞性黄疸の症例の肝でキノフォルムが娭 出されたが，これらの症例の肝組織は組織学的に一つの 特異なバターンを示した。すすなわちこの 4 例にはそれぞ れ異なつた原疾患（乙型肝硬変，脂肪性肝硬変，慢性肝 炎，咽頭癌による要液質）があるが，その上に認められ る変化は共通である。つまり肝細胞の空胞変性，特に核 に隣接した部位の空胞形成, Kupffer 星細胞の泡沫細胞 化, 細胆管の增生, 胆汁栓形成と炎症性反応などがるられ る. 胆汁栓の中には H.E. 染色て好塩基性深染まる物質 があり，塩化第二鉄でビリベルジンより暗い緑色反応を 示す. 肝以外では全例に膵煘に著明な変化がみられた。 この人体例の肝細胞拉よび Kupffer 星細胞の変化は動物 にキノフォルムを投与した時の变化とまつたく一致する が，動物に肝内閉塞性黄疸を引きおこす事はできなかつ た．電影的には，肝細胞に著明なミトコンドリヤの膨化 とクリステの消失，小胞体腔の拡大とその中のオスミウ 么好性物質の沈着, 核周辺の空胞形成, キノフォルム結 晶の沈着, 䟱面小胞体の増生などがみられた。

結論 : キノフォルムは既存の肝疾患があつたり，重篤 な他の疾患があると，臨床的に肝内閉塞性黄疸を引きお こす．その組織像はかなり特徽的で，肝細胞の空胞変 性，核周辺の空胞形成，Kupffer 星細胞の泡洙細胞化， 細胆管焱とそのあとの線維化などを引き拉こす，この場 合キフフォルムが肝内に証明される，肝細胞の変化は動 物実験で再現可能であるが，細胆管资，肝内閉塞性黄疾 はいまだ再現できない。 
25. 䌊胆管执張应における肝組像像特に肝内胆管の形 稳について

\section{東京大学小児外科}

土田 嘉昭，斎藤 純夫，石田 正統

東京大学病理志方 俊夫

東京大学小児科 白木 和夫，佐藤 富良

目的：総胆管扗張症と先天性胆道閉鎖症はそれぞれ独 立した別個の二疾患と考えられているが，多数の症例の 中には，区別の困難な症例もあり，また，両疾患の発生 病理を同一の原因比無声説もあり，疾患概念の区分は必 ずしも充分ではないよらに思われる。 また，肝組穖像の 変化についても，その変化がまつたく同一のものである か，何らかの相異点があるか，いまだ明らかではない，

演者らの一人は，1967年，本疾患に件5月旰障害を組織 学的变化と肝機能検查成瞔の両面から検討し, 乳児例に は, 肝障害の進行した虚例が多いことを指摘したが，今 回，その後の症例を加えて，肝組織像の変化をふたたび 娭討し，特に，先天性胆道閉鎖症との比較といらところ に，今回の研究の主眼を置いた。

対象と方法：過去 18年間に 東大第二外科で取扱つた 先天性総胆管拡張症 37 例（成人 4 例，小児33例）の5 ち，肝試切の行なつてある20例を研究の対象とした. 20 例の内わけは，1才以下が 6 例，1才〜 5 才が 9 例， 6 才以上が 5 例である。これら症例の組織所見 ( $\mathrm{H} \mathrm{E}$ 染 色）を検討した。

成績 : 線維化小葉满造の改策などの変化は，ほほ臨床 症状の程度と平行していた。臨床症状といつても, 黄 疸とは必ずしも直接平行せず, 無黄㡺の症例の中にも， 線維化の進行した症例があつた，年令との相関は，あま ク，明らかではないが，若年者に，この変化の進んた应 例が多くみられた。

胆汁栓・胆计色素などは黄㾝を伴ら症例にみられた。 肝細胞の巨細胞化は生後 2 カ月前後の症例にみられた か，その変化は giant cell hepatitis にみられるるのほ ぞ著明ではなかつた。 巨細胞化は 6 カ月以上の䒚例には みられなかつた。

肝内胆管の胎張は 1 例飞も認められなかつた. 先天性 胆道開鎖症においては, 生後 5 カ月頃より, 肝内胆管の 搪張が著明となつて来るに比し本症においては，まつた くこの变化が恋められず，最す大きな相異点と考えられ る. 一方, 小胆管の增生は多数の症例認められ, 臨床 症状の程度とほほ平行の関係がみられた。

結語 : 先天性胆道閉鎖症の総胆管拡張症の組織像は, 肝内胆管の形態に批いて, 相異点が見出される. 総胆管

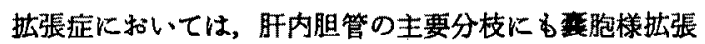
を伴ら例が少なくないが，このような microscopic level の胆管には，まつたく抬張のみられないことは興味深い 所見である.
26. 原吐性肝癌の病理形隹学的研究並びに剖换例にお ける $a_{1}$-fetoprotein の検索

久留米大学医学部第一病理学教室

神代 正道, 中島 敏郎

本学病理学教室の剖愉例に批斿る原発性肝癌について 若干の検索を行なつた，発生頻度は全剖検数 3,800 例 中, 原発性肝癌86例で2.26\%にあたり，そのらち肝細胞 癌79例, 胆管癌 7 例であつた。䀒硬变合併例恃, 肝細胞 癌79例中 49 例で $62.0 \%$, 胆管癌では 7 例中 1 例飞及られ た. 合併した肝硬変の型としては三宅の乙型肝硬変が大 部分をしめていた。

また，原発性肝癌86例中に日本住血吸虫症を合併して いたすのが 8 例あり, 日虫症の肝癌頻度は4.17士1.44\% で，非日虫症の肝癌頻度 $2.05 \pm 0.23 \%$ に比較して高い傾 向にあつた．192例の日虫症中にみられた 8 例の肝癌を 組織学的に挨查し, 日虫症と肝癌との関連性はないと思 われる例ああるが，多くは中等度以上の日虫卵を介在し 日虫性病変を保有していた，たたし，日虫症が肝癌の直 接病因となつているといら積極的所見は認め得なかつ た.

性別についてみると，男性75例に対し女性11例で約 $7: 1$ の割合となつている. 年令については, 男性の平 均年令かi $57.00 \pm 11.68$ 才，女性か：59.60土10.76才で ある. 年代别では，50才代が30例で最る多く，次いで， 60才代の24例，70才代の12例，40才代の11例，30才代の 6 例の順であつた. 最近の肝癌剖検例13例の剖検時血清 につき抗 $\alpha_{1}$-fetoprotein 馬抗血清 (平井, ミドリ十字) を用い二重平板免疫払散法により 10 例 $(76.9 \%)$ 飞陽 性, 3 例力陰性, 転移性肝癌, 他朖器癌, 肝硬変, 白 血病等の対照例においてはすべて陰性という結果を得 た.ささらに, 陽性, 陰性, 各例の肝癌組織像を比較検討 した. 陽性例は諸家の報告と同しくく Edmondson のI型 に多く見られた，また，陰性例に特異的な組織像の差異 はみられなかつた，なお，現在，営光抗体法を用いても 换索中である。 
27. a-Fetoprotein の Radio-immunoassay に関 する研究

$$
\begin{array}{lrrr}
\text { 神戸大学第二内科 } & & \\
\text { 井上 英士, 池原 } & \text { 英夫, 戸沢 } & \text { 辰雄 } \\
\text { 三木 章三, 石井 } & \text { 勝, 中田 } & \text { 晃 } \\
\text { 新光 毅 } & & & \\
\text { 神戸大学第二病理 } & & \text { 宮地 } & \text { 陽吉 }
\end{array}
$$

目的：現在，原発珄肝庼の猃断に用いられている $\alpha$ Fetoprotein (AFP) の免疫学的測定法ではA F P 陰性肝 癌が約10〜 40\%認められ，さらに陽性肝癌のほとんどが 末期癌であり，早期診断の可能性がきわめて困難である ことが諸家によつて報告されている。われわれ 40症例 の原発性肝癌において同様の成績を得，さらに個々の肝 癌患者血清A F P 定量值が病状経過とともに增加するこ とを認めている.このことからより高い感度を有する測 定法の開発が，診断率を高め早期診断を可能にするるの と考市, Radio-immunoassay 法の開発とその䧗床的意義 を明らかにすることを目的とした。

方法 : Radio-immunoassay (RI) は Hunter-Greenwood の方法で精製A F P : ${ }^{131}$ I を標識 し, Sephadex G-75 Column Chromatography により標識A F P を分嚾した。 結合 A F P と遊離A F P の分離は，硫安塩析を用いた一 抗体法之抗家鬼 $\gamma$-タロブリン抗体を用いた二抗体法に ついて感度, 精度, 再現性について検討した。 さらに一 元免疫払散法でA F P 陰性の肝癌 3 例, 肝硬変症 8 例, 転移性肝癌 8 例, 䀒炎 3 例, 健常人 5 例についてR I 法 により血清A F Pを测定した。また原発性肝癌30症例の 血清中に漂識A F P を添加し, Incubation 後の血清を電 気泳動法により分画LA F P 抗体の有無を捈索した。

成績：R I 法は二抗体法の方が感度, 精度においてす ぐれ，その感度は $10 \mathrm{ng} / \mathrm{ml}$ 以上で一元免度拻散法の的 300倍の感度が得られた。生娭で肝硬変症と診断され. 剖 検で小さな肝癌腫瘪を認めた症例と転移性肝癌の一症例 がR I 法でA F P 陽性を示し，他は全例陰性であつた。 また30例の原発珄肝瘦血清中全例にA F P 自己抗体の存 在は証明されなかつた。

結論 : 従来の测定法てA F P 陰性の肝茜症例中Radioimmunoassay で陽性を示す症例が存在したことはR I 法 が詢断串を高め，また早期馀断の可能性を有するるのと 考えられる.しかし枟移性肝癌です陽性を示す症例のあ ることはA F P のつ新しい意義を提供するすのと考え られる、さらに今後多数の应例について恰討を加え，A F P 做量測定法のるつ踇床的意美を明確にする必要があ 万.
28. 原発性胿㾤と血游胎児タンパクー免疫電気浸透泳 助法による血清胎児タンパク検出率

九州大学医学部第三内科

入佐 俊武, 富永喜久男, 平山千里

著者らは，原発性肝癌患者血清中の胎児タンパクの物 理化学的，免疫学的性状および血清胎児タンパクの量的 変動,ならびに肝癌組織像と胎児タンバク量との関係に ついて報告した，今回著者らは，原発性肝癌患者56例， 肝硬变应患者25例について，寒天内二重抬散法就よび免 疫電気泳動法，免疫電気浸透泳動法により血清胎児タン ヘクの検出を行ない，その意義について検討を加光たの で，その成縝を報告する.

原発性肝癌患者56例中，寒天内二重拡散法扰よび免疫 䉓気泳動法により血清胎児タンパク踢性のものは41例 （約73\%）であり，15例は陰性であつた．肝硬変症患者 25例はすべて陰性であつた。次に寒天内二重拡散法お。 び免疫電気泳動法により陰性であつた原発性肝癌患者15 例について，免度電気浸透泳動法に上り血清胎児タンパ クの検出を行なつたところ，15例中 9 例 $(60 \%)$ が陽性 であり，肝硬変症患者ではすべて陰性であつた，すなわ ち，免庭電気浸透泳動法に上ると原発性肝癌患者56例中 50例（約 $90 \%$ ）に胎児タンバクは陽性であり，肝細胞癌 と確診しえたすの15例中14例に陽性であつた，以上の成 樍上り，急疼電気浸透泳動法を利用することは，微量の 血清胎児タンバクを検出できるため，原発性肝癌の早期 診断にかなり有用であると考えられる。なお，部分的に 精製した胎児タンパクを抗原とし，免疫電気浸透泳動法 により，血中抗胎児タンパク抗体の検出を行なつたとこ ろ，上述の症例のうち，旰硬変症の1例に抗体を検出し たので，その意義について検討を加える予定である。 
29. 原発性肝瑮患者の a-Fetoprotein ID 法隆性例の 模討一特に CF 法について 国立大阪病院内科 藤田 昌弘，大网 照二 羽間 収治, 松尾 重雄 国立大阪病院研究検査科

舟㛢之, 植村富士男, 川井 一男 市立堺病院内科 松尾 雄二, 王子 喜一

目的： $\alpha_{1}$-fetoprotein(AFP) 性原発性肝癌の診断に有 用であるが，現在なお組維学的にこれが確諗されている にかかわらず换出され得ない例が存在する．今回われわ れはこの点に注目し，補体結合反応（C F 法）を中心に 二重免废拡散法（ＩＤ法）のみならす電気泳動法（ＩＥ 法)，监光抗体法などにより A F P の検出について検討を 加えた.

方法：抗AＦＰ血清は栄研の協力を得，6力月未満の 人胎児および肝癌患者腹水から硫安塩析を行ない，D E A Eセルローズカラムクロマトクララフィにて粗精製A F Pを作制し，これを兔疫抗原として家鬼保度免疫を行 なつた．得られた抗血清を正常人血清にて吸収し使用し た，C F法は Kolmer の微量法により，Hemolysin は25 単位，抗体は 2 単位，用いた抗血清はその抗体力価につ いては，Box titration の結果票準とした抗原に対し抗体 の1単位は512倍であつた．ID法では16倍まで沈降線 が出現した。研究対象は原発性肝稳を含む各種疾患 117 例の血清および腹水て検討を加えた。

成績：A F P のC F価は量的に ID, IE 法によるるの と相関関保が得られた，剖検，死後生検および手術切除 材料上り組織学的に診断確定せる16例の原発珄肝癌て， I D法陰性 8 例中 (50\%)，I E法にて1例，C F法では 7 例飞愉出され，C F 法によれば $93.8 \%$ の陽性率を得 た。なお臨床上肝癌と䛦断された 7 例を加えると，A F Pの陽性率はID法60.9\%，C F法では95.2\%を示し た. C F 法陽性例 5 例では蛍光抗体法にて肝癌細胞のA F P 库生を確喼した，次に組織学的に確診した転移性肝 癌 5 例や之の他の悪性腫瘍22例，僈性肝炎18例，急性炎 旰 9 例ではいずれるID，IE，CF 法にて陰性で，肝硬变 患者35例中 2 例老除きC F 法にてる陰性であった。この 2 例については現在生存中で，肝癌の有無について鋭意 検索中である，経過観察中くり返し測定し得た慢性肝炎 および肝硬変例で，ID，IE 法陰性でC F 法にて陽珄を 得，原発性肝癌の早期㻅断に寄与し得た例があるが，肝 癌例で死亡前には一般にC F 洒は増加するが，不変，減

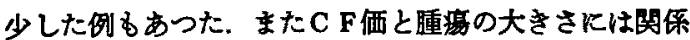
がなかつた。

結論：CF法によるAFPの検出はID法，IE法に 比して鋭敏でしかる特異性が十分認められる故，現時点 ではA F Pの検出に際してはCF法を用いるべきである と考える.
30. $\alpha$-Fetoprotein の测定法と臨床的意戒 神戸大学第二内科

石井 勝, 戸沢 唇雄, 池原 英夫

井上 英士，三木 章三，中田 胃

新光 媇

目的：血清中に $\alpha$-Fetoprotein(AFP) を証明すること が，原発性肝癌の診断にきわめて高い価值のあることが 知られ，今日ではA F P の免疫学的測定がルーチン肝疾 患梌查法の一つとして加えられようとしている. そこで われわれは，1）各種のA F P 测定法の比較検討，2） 血清 A F P 定量値の経日的变動と病状経過および治療効 果との関保，3）原発性肝瘦とオーストラリア抗原 (Au 抗原),4） A F P K上る早期診断の可能性. 以上 4 点に ついて 検討し，AFP test の むつ臨床的意義を明らかに することを目的とした，

方法：1）测定法は，Micro-Ouchterlony（MO）法, Immuno-electrophoresis (IE) 法, Electro-syneresis (ES) 法, Electrodiffusion(ED) 法, Single radial immunodiffusion(SRI)法を行ない，簡便さ，感度，足量性，測定の 迅速性等について比較検討した．2）ＳＲＩ法により血 清A F P の定量を行ない抗重湯成 (5-Fluorouracil) 投与 群と非投与群について経日的定量値の変動を見た．3） 40症例の原発性肝癌について S R I 法によるAu 抗原の 測定を行なつた４） 40症例の原発珄肝癌についてS R I 法と Radio-immunoassay 法の診断率について検討し た.

成樍：測定法の简便さでは MO, SRI 法が良く, 感度 では ES, SRI 法が最良でA F P 0.3mg/dl以上検出でき た. MO，ED法は 1.0mg/d1以上であつた. 定量性はSRI， ED 法がすぐれていた。迅速性ではES 法が20分，ED 法 2 時間，他は12時間以上であつた。抗畽晹剤非投与群 では臨床症状の悪化ととすに血清A F P 值が上昇し，投 与群では投与前のA F P 值の上昇が一時見られなくなり 非投与群に比し延命効果が見られた４0症例中 4 例に Au抗原を検出したが血清A F P 值とは関連性を恝めなか つた．S R I 法で40例中36例A F P 陽性で，陰性 4 症例 の中 R I 法で 1 例陽性を示した。なおＲＩ法で陽性を示 した 1 症例は比較的早期の肝癌であつた。

結論 : ルーチン检査としてS RI法が，簡便さ，感 度，定量可能な点から最適である．AＦＰの程日的定量 は病状経過，抗腫湯剤効果判定の指骠となる。現在，一 般に用いられている测定法では早期診断の可能性が少 く，今後，高感度でしかむルーチン検査として簡便な測 定法の開発が必要である。 
31. 原発性肝数切除庭例の $\boldsymbol{a}_{1}$-fetoprotein 定青值の 变彭

$$
\text { 東京大学第一外科 }
$$

菅原 克彦，小暮 洋嘎 間中 純也, 白合 徹也

東京大学第一内科遠藤 康夫

昭和45年度に原発性肝癌を 5 例切除し得たが，3 例に 陽性であつたので, Mancini 法でA F P を定量し，蟫床 経過を覾察，対比した。

その結果

1. 不定の消化器症状がある段階で, 原発性肝癌患者 をスクリーンし得る可能性が示唆された。

2. A F P 産生能の强い例では再発を知る道確なParameter となり，化学療法を行なら根拠を与える。

3. A F P 産生能は肝癌の組織型, 異型度と関保があ り，経験例では trabecular type, Edmondson II 型に産生 が多かつた、畽㻛の大きさとの関保は䀒シンチグラム， 剖娭所見から類推すると，AＦＰ量との間に必ずしる相 関関係はなかつた。しかし同一例では肝癌の進行をある 程度示すようである。

4. A F P 陽珄例では従来演者らが重視してきた動脈 造影像所見は，畽韵と脈管との関俰を知るために特に価 値がある。
32. $a_{\mathrm{i}}$-Fetoglobulin 陧性を示した肝転移周裙に関す る模討

国立がんセンタ一病院外科，内科，蹦床検查 部, 病理部

$$
\text { 北岡 久三, 吉川 謙藏, 向島 達 }
$$$$
\text { 厷田 映五, 岡崎 伸生, 服部 信 }
$$

目的：Bergstrand（1956）により立証された $\alpha_{1}$-Fetoglobulin は未開発領域とされていた原発性肝癌の診断, 治療に曙光を見出し得たかに見光る.一方，偽陽性例， ことに胃癌の肝転移の報告はきわめてまれであり，その 検討は今啳の問題である. 国立がんセンター病院におい て経験された 5 例の $\alpha_{1}$-Fetoglobulin 陽性肝転移胃癌に ついて，主として病理組織学所見を中心として梌索した ので報告する.

方法ならびに症例：1）抗 $\alpha_{1}$-Fetoglobulin 抗体を用 いて，単（純）拡散法による本物質の定量化を確立した (向島).抗 $\alpha_{1}$-Fetoglobulin の特異抗血清は肝癌患者の 腹水より， $\alpha_{1}-\mathrm{F}$ 分画を抽出し，家鬼に兔疫し得た。

2）昭和45年11月より術前の胃癌患者および再発胃癌 患者の注註全例飞 $\alpha_{1}$-Fetoglobulin 反応を施行した。

成績：1） $\boldsymbol{\alpha}_{1}$-Fetoglobulin の陽性率：成人肝癌 93例 中77例 $(82.8 \%)$ ，小览肝瘦 7 例中 7 例，眙坚性癌 8 例中 4例か陽性を示した，転移性肝癌と䛦断されだ80例中 5 例 ( $6.3 \%)$ が陽性を示したが，これらはすへて胃瘦の 肝転移と考えられるすのであり，他の埛器癌の肝転移の 症例は陰性であつた５例の定量值はそれぞれ，13u，15 u, 25u，98u，2,150u を示した. 13u，2,150u を示した 2 例は剖検がなされていないが，肝転移よりをしろ肝虽 の重複を否定できない，肝転移を伴わない胃癌 103例の 衍前検查では全例陰性であつた. 25 uを示した症例は肝 左葉に鷄卵大の転移巣を認めたが, 衍前は陰性であり， 術後 6 カ月たち肝転移巣が厸範に形成され，はじめて陽 性化した。

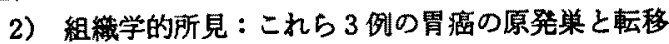
巣の組織像の共通点は, 腫湯細胞は索状ないし小葉状に 排列し，腺腔形成は不鮮明ながらかなり認められる。腫 瘍細胞は大型で，胞体に富み，エオジン好性で徽細顆粒 状を呈す. 核はクロマチンに富み，核小体はやや鮮明。 間質法わ好てしく，毛細血管からのみ形成されてい る. 以上の所見から肝細胞癌とかなり類似した構造をる つ比較的低分化の腺癌であると考えられた。

結論：1）少数例の検索であるか，胃癌細胞で $\alpha_{1}$ Fetoglobulinを産生するるのがかなり存在するであろう. 2）壆の本態の解明には，胎生期の生化学，免疫血清学 的研究が，その焦点の一つになることを示唆する。 
33. 姡婊における $\alpha_{1}$-Fetoprotein 検查について 国立相模原病院内科 永森 静志, 信太 隆夫, 島野教入郎

正常人血清中には存在しない胎児特有の $\alpha_{1}$-Fetoprotein (以下 $\alpha_{1}-\mathrm{FP}$ と省略) が肝癌患者火恃異的かつ高 率に出現するために，最近では優れた検查法として注目 されている。他方，渡部らの研究によれば，娃娠ラット 血清中には $\alpha_{1}$-FP が証明され，分婏ととむに，まつた く消失することにより胎児の $\alpha_{1}$-FP が冊体に移行した すのと推定している。. また，Tatarinov は自然流産の妇 人血清中に $\alpha_{1}$-FP を認めたと述べている. しかし，現 在までに，この報告以外飞妊婦より $\alpha_{1}$-FP を倹出した 報告はみられないようである。われわれは，眙児の $\alpha_{1}$ FP が冉体に䔟行する可能性を考えて，この点について 検討したので，成績の一部を報告する。

主として，産婦人科外来の患者（そのらち約90\%は妊 婦である）血清を使用L, Single Radial Diffusion Method (Immunoplate KOWA) を用いて检索した，現在ま でのところ，約 200例について行ない，約10\%に沈降輪 を疑わしめるリングを認めた。これらの陽性例とみな されたのは，すべて，2〜5力月の娃婦血清で，非妊 婦 (Erosion, Myoma, Vaginitis，など) の血清には認め られなかった、これらリングの性状注，䀒癌患者の陽性 例と比較すれば, 稀薄である.

この観察から直ちに，胎児 $\alpha_{2}$-FP が冊体化移行した ののとは断じえないが，妊婦血清，特に 4 カ月前後の例 に見られた点などを考え，移行の可能性があるすのとみ てさらに検討中である。

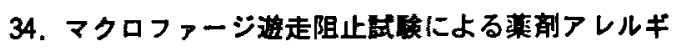
一性肝炎の研究

大阪市立大学第 3 内科

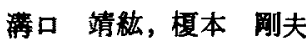

阴奈 丈之, 山本 祐夫

大阪市立大学生化学教室 森讯 成司

私たらは前に，薬棛フレルギー性肝炎の起因薬骩を険 出する方法として, リンバ球, 特に比重の重い小リンハ

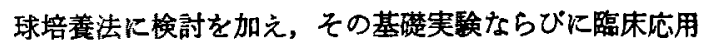
についての成績を報告した，最近新しく開発されたマク ロフフージ遊走阻止試験（MIF test）は，暒延型アレ ルギー反応の強さを in vitro で測定でき，臨床応用す可 能であり，さらに，本態の不明であつた遟延型フレルギ 一反応を物質のレベルで解明する手掛を与兄るものと注 目されている.

今回はこの MIF test を用いて菜剤による肝障害の疑 いのある症例を検討し，起因薬剤のフレルゲンとしての 関与を確認しえたので報告する。

実験方法：患者の末梢血10〜15ml をへハリン添加で 採血し，操作後に $1 \times 10^{6} / \mathrm{ml}$ となるように培養液を加兄 て、リンパ球細胞浮遊液を調整する。これに患者血清お。 よび疑わしい起因楽珴を添加し，48時間培盖の後，上清 を採取する，一方，正常モルモットの腹腔内洤出稩胞を 採取し毛細管につめ, Sykes-Moore Tissue culture chamber に入れて，上述の細胞培盖上清を加え $37^{\circ} \mathrm{C} 48$ 時間 培堆する. その際，毛細管口より遊出して来るマクロフ アージの遊走面積を測定してMI F の生成の強さを求め た. 対照実鈋は同一条件の実験に抗原を加えないで行な い, 奶照実験の遊出面皘々抗原添加実鍳のそれとを比效 して遊走指数（MI）を算定し\%で現わした．MIか770 \%以上の場合は遊走阻止効果が明確でない之判断した。

実験成樍：症例 1.63 才男，老人性精神病の疑にて的 2 週間のクロールプロマジン 200Mgの投与を受け，次い で黄疸が出現した．腹腔鏡，肝生梌で肝内胆计らつ事の 像が認められた. MIF test では、クロールプロマジン の添加に上りM I は23\%を示し，本症例の肝障害の成立 機序にはクロールプロマジンによる細胞性免度が関与し ていると判断された。

症例 2.18才女子, 預部の化脹䉾のため, エリスロマ イシン・エステレート800多の投与を受け, 全身発疮, 次いで黄庭の発現をみた。肝機能模查成猜では肝内胆计 らつ济症のパターンを示した. MIF test では, ェリス ロマイシン・エステレートの添加によりMI は48\%を示 し，本剤によるアレルギー性肝炎と判定された，目下さ らに他の应毗いいて検討中である. MIF test は，菜

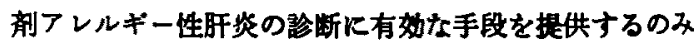
ならず，旰炎成立におけける細胞性免疫の関与の問題に重 大な示瞚を与えるるのと考える。 


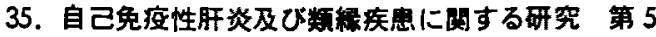
報 細胞性抗体の梌索

京都大学深頼内科 沖本 芳春, 中川 潤

伊藤 害一, 深瀨 政市

静岡県立中央病院消化器科前田 耕治

目的 : ある種の肝障害の病変の理解注自己兔疫現象 の介在を想定しなければその解秎が困難であり，事実自 己免疫現象の存在か略確実之考之られるいくつかの証拠 がある. Mackey らにより提唱されている自己免疫性肝 炎は自己兔疫性機序の介在が有力視され，これらの問題 を解明する手愁りを与える臨床例である。しかし障害惹 起因子の詳細なる機序については細胞性抗原抗体あるい は抗原抗体複合物等の考えがあり，まだその詳練に之し

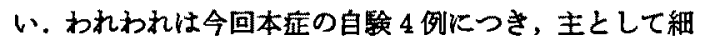
胞性抗体の果す役割を検討した。

方法：細胞性抗体を検討する方法には種々なるもの があるが，患者末梢 リンハ球の培着液中に肝䋆を添加 し，幼若化現象を観察する方法があるが，今回われわれ は上記の方法に加えて，さらに忠実かつ鋭钽なる途延型 過敏反応とされるマクロファージ遊走阻止現象を, 北欧 一派とハーパードー派の両方法を用いて央施した。 すな わちへパリン加静脈血よりリンハ球を分離培養し David らにしたがい自己免疫性肝炎患者の肝眝を添加した。な 拈抗原側の対象として変性D NAを，一部の例では Au 抗原等を用いる他，PHA を新鮮自己血清とともに添 加，72時間培盖を行なつた．集めたリンフォカインにつ き，モルモット腹腷出液細胞を用いマクロフォージ遊 走阻止因子（MI F）を検討した。 また S $\phi$ borg らにし たがい、Dextranにより赤血球を分離した末梢白血球を用 いて毛細管法に上り旰㟋添加培着に括ける遊走阻止現象 を観察した。 また培着りンバ球につきD N Aへの TdR${ }^{3} \mathrm{H}$ のとりこみを Robbins らの方法て測定した.

成績ならび結論：自己免疫性肝炎症例では，対照と した慢性肝炎, 薬物性肝炎例飞比し, 肝程添加に上り リンパ球への TdR- ${ }^{3} \mathrm{H}$ とりこみに:沉進を認める症例が あり，また抗核抗体陽性例では，変性D N A の添加によ り軽度のとりこみ亢進が 認められた症例があつた. $\mathrm{S} \phi$ borg らの方法あるいは，David らの方法により培着液中 に肝䂾添加を行ならとMI F值に有意の差が琶められた 症例があつた。な和本方法の抗原特異性についての成績 あるいは本症に怙ける抗原の考察上対照として1〜2の 抗原を添加した成績, 他の自己免疫性疾患についての成 耫の上から興味ある成縝が得られた。 またわれわれの本 自倹20例中 2 例にのみ $\mathrm{Au}$ 抗原陽性を呈したがその中 1 例は肝硬変次いで肝細胞瘐の発生を見たのでこの点も考 察し上記の方法による成綪を述べ.
36. 自己免疫性訮次及び類緑疾患に閶する研究. 第 6 報 自己兔疫性肝资の発症に閏する道公学的美因 京都大学深瀬内科 金 相福, 玉井 義朗 永口千里，伊藤 重一，深瀬 政市

目的：肝炎遷延化の機序に関しては宿主側の条件, 病 原ウイルスの体内持続，あるいはAu抗原を取囲んでの 免疫機構の異常等の面から考察されている. われわれは 宿主側の条件を検討する上に，自己免没性肝炎は恰好の モデルと見做し得る疾患と考えている. 今日，一般に自 己免疫性疾患の発生要因には, 遗伝的素因の関与が, 重 視されているが，その詳細については明らかてなく，特 に自己免疫性肝炎については，そうである.

今回自験20例の中，家系調査を行ない得た 6 症例の家 系についての成綪を基にして, 自己兔度性肝资の発症に 関する遗后学的素因について述べる.

万法 : Proband となつた 6 症例のほとんと総ての家族 について, 血中の $\gamma$-globulin 值の測定, 蛍光抗体間接 法を用いての，血中抗核抗体，抗平滑筋体，T R C 法に 上る抗甲状腺轨体の測定を行なつた。 また，全例につを 同時に, 血中 Australia 抗原の検索, および一部症例で は，抗体の飧索を，行なつた.

成績：6虚例中 2 例においては，それぞれ，同胞, 長 男に自己免度性肝炎の発症を見た。ま 6 例中 5 例の家 系江批、ては， $\gamma$-globulin の高值，抗核抗体，抗甲状腺 抗体の陽性例を, 可成り高率に認め, 抗平滑筋抗体偽 陽性例も散見された。しかし血中抗体陽性例，および， 高 $\gamma$-globulin 血症を示した例においては，性的分布， 年令別分布に和いて，明膫な特徵は，認め難かつた。 た，臨床的には，旰障害を認めた症例はなく，肝疾患以 外のものとしては、リゥマチ性関節炎, ベーセット氏 病，慢性甲状腺炎が認められた。A A 抗原は, proband で は， 6 例中 1 例飞陽性を，家族では29例中 2 例に，陽性 を認めたに過ぎなかつた。

結論：高 $\gamma$-globulin 血䒚，あるいは，血中の抗核抗 体, 抗甲状腺抗体の陽性例は, 抗体産生機構の異常之見 做し得る.これら異常所見を呈した例を家系図から眺め ると, autosomal dominant の遺伝形式をるつて, 免没異 常の体質素因が，遗伝している点が注目される。

一方，自己免疫性肝炎は，文献例，自験例之もに，女 性に好発しているが，NZBマウスを用いた実験的自己 兔疫症の成樍等を考虑すると, 自己免疫性肝炎の発症 は，一定の遗云的素因の上に，発应するが，性は，これ を修飾する因子であると考えられる，また，本症の発症 に関し，Au 抗原が関与するとの，積極的な成績は得ら れなかつた. 